\title{
USING COLLABORATIVE LEARNING EXERCISES TO TRANSFER PERVASIVE SKILLS: SOME SOUTH AFRICAN EVIDENCE
}

\author{
Monique Keevy \\ University of Johannesburg \\ mstrauss@uj.ac.za
}

Received: October 2014

Accepted: June 2015

\begin{abstract}
Globally, academics have adapted their teaching methods to more active methods, such as collaborative learning exercises. Research provides evidence of the value of collaborative learning exercises in the development of pervasive skills. The objective of this paper is to examine the use of collaborative learning exercises by academics in South Africa $(S A)$ - a developing country - and to obtain their views on the effectiveness of this method in transferring pervasive skills to students. An electronically administered questionnaire was sent to accounting academics working at universities accredited by the South African Institute of Chartered Accountants. The findings of this paper reveal a gap between the use of collaborative learning exercises by SA academics compared to that globally. This gap can be attributed to a lack of awareness by SA academics of the competencies that can be developed using collaborative learning exercises, or the application of alternative teaching methods.
\end{abstract}

Keywords

Academics, chartered accountants, collaborative learning exercises, competencies, competency framework, development, pervasive skills

Ms M Strauss (neé Keevy) is a senior lecturer in the Department of Accountancy, University of Johannesburg, South Africa. 


\section{INTRODUCTION}

The business world has changed considerably over the last two decades in terms of technological innovations, changes in the economic environment, increasing regulations and the globalisation of the world's economy. These factors have reformed the business environment, which has resulted in professional accountants being expected to master not only technical skills but also pervasive skills (American Accounting Association (AAA), 1989; Albrecht \& Sack, 2000; Stovall \& Stovall, 2009).

The move to formulate changes in university accounting teaching and learning practices was initiated by the AAA in 1986 (AAA, 1986; Cotton, Rainsburg \& Scott, 2002). Subsequently, the Accounting Education Change Commission (AECC) was formed to facilitate improvements in the accounting curriculum (Sundem, 1999; Cotton et al., 2002), since "future accountants would be expected to be as proficient in communication skills as they are with numbers, as comfortable in committee as they are with a calculator, as ready to learn and apply a new theory as they are to interpret an old rule" (AAA, 1995: n.p.). In light of these changes, the International Federation of Accountants (IFAC) developed a set of education standards in 2003 encompassing both technical competencies and pervasive skills (IFAC, 2010). Consequently, the IFAC member bodies had to align their qualification models to the IFAC (Van der Schyf, 2008).

In 2008, the South African Institute of Chartered Accountants (SAICA) introduced a Competency Framework (CF), which encompassed both technical and pervasive skills (SAICA, 2009), the latter being the focus of this paper. Previously, South African (SA) academics were not formally tasked in ensuring that pervasive skills were transferred to aspirant chartered accountants (CAs). However, in light of the development of the CF, academics now have to ensure that each pervasive skill is addressed in their academic programmes and that evidence of this is provided to SAICA (SAICA, 2011).

Pervasive skills are the so-called soft skills, which are also described as behavioural skills, nontechnical skills, employability skills and interpersonal skills (Brungardt, 2009) in the literature. According to the Oxford Dictionary (2014a), soft skills are "personal attributes that enable someone to interact effectively and harmoniously with other people". Furthermore, graduates are expected to demonstrate more than subject knowledge to meet the needs of their employers (Cargill, Gammie \& Gammie, 2002; Brungardt, 2009; Gammie \& Joyce, 2009). These attributes are therefore paramount to the profile of professional accountants (De Villiers, 2010; Low, Samkin \& Liu, 2013). Academics have been blamed for not equipping graduates with pervasive skills (AAA, 1986; AECC, 1990; Thomas 2000; Drennan \& Kavanagh, 2008; Ballintine \& McCourt Larres, 2009; Barac, 2009; Brungardt, 2009; Coetzee, Joubert \& Oberholzer, 2009; Stovall \& Stovall, 2009). Thus, recent accounting literature still calls for aspirant professional accountants to be equipped with these competencies (Drennan \& Kavanagh, 2008; Stainbank, 2009; Stovall \& Stovall, 2009; De Villiers, 2010; Frank, Gradisher \& Ofobike, 2010; Low et al., 2013)

De Villiers (2010:10) conveyed that even though the accounting curriculum is already full, academics "will need to find innovative ways to deliver on the demands of stakeholders if they wish to remain relevant". Cargill, Gammie and Hamilton (2010) share the notion that universities need to develop their own programmes to ensure that aspirant professional accountants are competent in all skills, which should then be substantiated to their respective bodies. Authors have stressed that in order to address these skills, accounting education should move away from the traditional lecture-based classes to more action-orientated and studentcentred approaches (AECC, 1990; AAA, 1999; Albrecht \& Sack, 2000; Jayaprakash, 2005). 
Students should be active, rather than passive participants in the learning process (AECC, 1990; AECC, 1998; AAA, 1999; Beattie, Collins \& McInnes, 1997; Boyce, Kelly, Williams \& Yee, 2001), as this enhances the development of all skills (AECC, 1998; Davis, Dudley \& McGrady, 2001; Frank et al., 2010) and retains information for extended periods (Sullivan, 1996). Francis and Samkin (2008:236) convey that "effective learning should be an active and dynamic process".

The method of using collaborative learning has been described as action-orientated and student-centred (Sullivan, 1996). This method was highlighted in the literature given that graduates are expected to work in teams when entering the accounting profession (Berry, 1993; Albrecht, Clark, Smith, Stocks \& Woodfield, 1994; Stovall \& Stovall, 2009; Low et al., 2013). In the work environment, professional accountants will be required to "exchange ideas, express opinions, solve problems and resolve differences in a timely and proper manner" with colleagues and clients (Stovall \& Stovall, 2009:102). Furthermore, graduates will be required to work effectively with colleagues and senior staff members (Low et al., 2013). Collaborative learning results in a "combination of observation, consultation, mutual exchange of information and a process of osmosis" (Eraut, Alderton, Cole \& Senker, 1997 in Cheetham \& Chivers, 2001:262). The IFAC (2010) advocates that working collaboratively is essential since it is these skills which enable professional accountants to interact with others, motivate and lead others, resolve conflict and delegate tasks. Furthermore, it has been expressed that "learning is enhanced when it is more like a team effort than a solo race" (McVay, Murphy \& Wook Yoon, 2008:47). Accordingly, SAICA have expressed that collaborative learning should be part of the academic programme of aspirant CAs (SAICA, 2011).

Many of the benefits pertaining to collaborative learning have been documented in the accounting literature; however, none of these benefits has been presented in the context of SAICA's pervasive skills. SAICA's pervasive skills echo the skills and values of IFAC, and are comparable to the competencies of other professional bodies (Van der Schyf, 2008; SAICA, 2009). Consequently, it follows that SAICA-accredited academics are not alone in the challenge of transferring pervasive skills to students. Therefore, this study will aid SAICA-accredited academics in the use of collaborative learning exercises to transfer SAICA's pervasive skills. Similarly, it will also provide insight to other academics, both locally and internationally, on the competencies that can be transferred employing collaborative learning exercises.

The remainder of this paper is organised as follows: the next section presents the objective and limitations of the study. The sections that follow describe the theoretical framework of the paper, the research method and the empirical findings. Conclusions and recommendations drawn from this study and areas identified for future research are presented in the last section.

\section{OBJECTIVE AND LIMITATIONS OF THE STUDY}

Over the past three decades, considerable changes have ensued in the skills required of professional accountants (AAA, 1986; Sundem, 1999; Albrecht \& Sack, 2000). Globally, academics have adapted their teaching methods to more active methods (AAA, 1986), such as collaborative learning exercises (Adler \& Milne, 1995; Adler \& Milne, 1997; Ballantine \& McCourt Larres, 2009). Consequently, the objective of this paper is to examine the use of collaborative learning exercises by academics in SA - a developing country - and to obtain their views on the effectiveness of this method in transferring pervasive skills to students. 
This study has four limitations: (a) the summary did not differentiate between the various types of collaborative learning exercises. Therefore, the different ways in which collaborative learning exercises can be used, and which pervasive skills can be developed in this manner will be explored in a future study; (b) The questionnaire was limited to the perceptions of accounting academics at SAICA's accredited academic programmes; (c) The questionnaire merely asked academics whether they used collaborative learning exercises in their academic programmes and whether they deemed that this method could effectively transfer pervasive skills to students. The questionnaire did not ascertain why academics are not using collaborative learning exercises. This will be addressed in a future study; and (d) Lastly, a possible limitation of the literature review is that insufficient evidence was obtained. However, given that each competency is linked to one or more source, this does not pose a problem given that another researcher could have come to the same conclusion using other evidence.

\section{LITERATURE REVIEW}

\subsection{The nature of collaborative learning exercises}

The literature cites several definitions in relation to collaborative learning. Cottell and Millis (1992:97) describe cooperative learning as "a structured form of small group work based on positive interdependence, individual accountability, appropriate team formation, group processing, and social skills". In addition, the Oxford Dictionary (2014b) defines collaborate as to "work jointly on an activity or project". Teamwork is defined as "the ability to share responsibilities, confer with others, honor commitments, help others do their jobs and seek help when needed" (Houghton \& Proscio, 2001:6). Collaborative learning requires students to be placed in smaller groups and to work jointly on a task (Ballantine \& McCourt Larres, 2009). Consequently, the team members "share a common goal" (0'Neil, Lee, Wang, Mulkey, 1999, in Brungardt, 2009:13).

But what is the ideal size of a team? Authors have varied opinions in this regard. Some suggest that having five team members is the most effective (Sullivan, 1996, in Stainbank, 2009), while others view having four team members to be more suitable (Cottell \& Millis, 1992). Certain authors favour between three and six members in a group (Odafe, 1994 in Miglietti, 2002). It has been suggested that three members to a group is best, since having only two members will place too much strain on the pair and having four members becomes too difficult to manage (McVay et al., 2008). However, authors are in agreement that the group should be small (Ballintine \& McCourt Larres, 2009).

Regardless of the size and dynamic of the group, authors are clear in stating that the academic acting as facilitator plays a pivotal role in the collaborative learning process (Ballintine \& McCourt Larres, 2009). The academic's "role becomes planner, facilitator, and occasionally participant" (AECC, 1995). Consequently, facilitators should provide clear instructions to students (Rainsbury \& Malcolm, 2003 as quoted Hu, Kern, McGuigan \& Weil, 2013), provide structure to the class (Jones, 2013), and regularly engage with the group (Cottell \& Millis, 1992). In this way, the facilitator will discover if team members are ill prepared or are not partaking in group activities (Cottell \& Millis, 1992). It has been posited that the following five essential elements are required for effective collaborative learning: (1) "students must sink or swim together"; (2) students need to interact with one another (3) team members need to be made individually accountable (4) there should be social skills such as leadership roles, 
communication and methods to avoid conflict and (5) group reflection should take place after the completion of a task (AAA, 1995).

Working collaboratively is not plain sailing. For example, the difficulties reported in the literature pertaining to the facilitator are loss of control (Maesin et al., 2010), not providing clear instructions to the groups (Lehmann, Rose \& Strand Norman, 2004) and being ill-prepared in the use of this method (Maesin et al., 2010, Avramenko, 2012). However, this can be overcome by sending the facilitator for training (AECC, 1998). The problems conveyed in the literature relating to the group, suggest that group members may not contribute equally to group activities (Ballintine \& McCourt Larres, 2009; Avramenko, 2012), conflict may arise within the group (Lehmann et al., 2004), and problems may be experienced with group dynamics (Avramenko, 2012). The problems set out above may however, be managed by making group members individually accountable (Lehmann et al., 2004), by having them perform peer evaluations on their fellow team members (Miglietti, 2002), and regularly rotating group members (Cottell \& Millis, 1992). Moreover, academics stated that collaborative learning is not geared for large classes (Maesin et al., 2010; Cunningham, 2008 as quoted in Everaert \& Opdecam, 2012), and that this method of teaching is more difficult than the traditional classroom lectures (AECC, 1998). This problem can be solved by dividing classes into small subgroups to ensure student participation (De Villiers, 2010).

Collaborative learning exercises can take place in many forms and in combination with other methods namely, group presentations (Adler \& Milne, 1997; Stainbank, 2009; Maesin et al., 2010), group assignments, group discussions, games within the group, case studies performed in a group (AAA, 1995; Adler \& Milne, 1997; Anderson \& Cunningham, 2005; Dyball, Reid, Ross \& Schoch, 2010; Maesin et al., 2010; Avramenko, 2012; Van der Merwe, 2013) and in conjunction with group role-playing activities (Maesin et al., 2010; Paulson, 2011). Group-based online activities can also be conducted (Hu et al., 2013).

However, regardless of how this method is employed, the accounting literature provides a host of competencies that can be developed using collaborative learning exercises, as set out below.

\subsection{Summary of the pervasive skills that can be developed by employing collaborative learning exercises}

This section provides a summary (TABLE 1) of the pervasive skills that developed using collaborative learning exercises. In order to obtain the summary, a literature review was conducted. The literature review was used to identify and retrieve empirical studies that were relevant to whether collaborative learning exercises can be employed to develop SAICA's pervasive skills. The search was limited to empirical studies that were written in English and that were within the accounting literature and/or accounting profession.

To ensure coverage of empirical studies on the topic, the literature review included peerreviewed journal articles, conference papers, master's thesis and doctoral dissertations. The keywords and descriptors used in the search included accountants, accounting, collaborative learning, cooperative learning, development, education, ethics, groups, group working, learning, professional skills, skills development, small groups, soft skills and team work. The sources comprised eight key databases and one library catalogue.

SAICA's pervasive skills were divided into three categories, namely ethical behaviour and professionalism (IA), personal attributes (IB), and professional skills (IC) (SAICA, 2009). The 
literature review was condensed into a summary by identifying whether collaborative learning exercises can be employed to develop SAICA's pervasive skills. Therefore, each pervasive skills was linked to the literature review sources, as set out below.

\section{TABLE 1: Summary of the pervasive skills that can be developed using collaborative learning exercises}

(IA) ETHICAL BEHAVIOUR AND PROFESSIONALISM

(IA) 1. Protects the public interest

AAA, 1999; Cheetham \& Chivers, 2001; Foster \& Lepard, 2003; IFAC, 2010; Van der Merwe, 2013.

(IA) 2 Acts competently with honesty and integrity

AAA, 1999; Cheetham \& Chivers, 2001; Foster \& Lepard, 2003; IFAC, 2010; Paulson, 2011; Van der Merwe, 2013.

(IA) 3. Carries out work with a desire to exercise due care

Adler \& Milne, 1997; AECC, 1998; AAA, 1999; Davey, Haigh \& Kelly, 1999; Thomas 2000; Cheetham \& Chivers, 2001; Miglietti, 2002; Foster \& Lepard, 2003; Anderson \& Cunningham, 2005; IFAC, 2006; Ballintine \& McCourt Larres, 2009; Hong Kong Institute of Certified Public Accountants (HKICPA), 2011; Paulson, 2011; Van der Merwe, 2013.

(IA) 4. Maintains objectivity and independence

AAA, 1999; Cheetham \& Chivers, 2001; Foster \& Lepard, 2003; IFAC, 2010; Paulson, 2011; Van der Merwe, 2013.

(IA) 5. Avoids conflict of interest

AAA, 1999; Cheetham \& Chivers, 2001; Foster \& Lepard, 2003; IFAC, 2006; IFAC, 2010; Van der Merwe, 2013.

(IA) 6 Protects the confidentiality of information

AAA, 1999; Cheetham \& Chivers, 2001; Foster \& Lepard, 2003; IFAC, 2006; IFAC, 2010; Van der Merwe, 2013.

(IA) 7. Maintains and enhances the profession's reputation

AAA, 1999; Foster \& Lepard, 2003; IFAC, 2006; Van der Merwe, 2013.

(IA) 8. Adheres to the rules of professional conduct

AAA, 1999; Foster \& Lepard, 2003; IFAC, 2010; Van der Merwe, 2013.

(IB) PERSONAL ATTRIBUTES

(IB) 1. Self-manages

Cottell \& Millis, 1992; Adler \& Milne, 1995; AAA, 1995; Johnson, Johnson \& Smith, 1991, as quoted in Kimmel, 1995; Sullivan, 1996; Adler \& Milne, 1997; Miglietti, 2002; Anderson \& Cunningham, 2005; Ballintine \& McCourt Larres, 2009; Stainbank, 2009; Stainbank, 2010; Paulson, 2011; McConnell \& Sasse, 1999 as quoted in Everaert \& Opdecam, 2012.

(IB) 2. Demonstrates leadership and initiative

Riccio \& Sakata, n.d.; Cottell \& Millis, 1992; Berry, 1993; Albrecht et al., 1994; Adler \& Milne, 1995; Adler \& Milne, 1997; Albrecht \& Sack, 2000; Rooff-Steffen, 1991, as quoted in Thomas 2000; Foster \& Lepard, 2003; IFAC, 2006; Race, 2001, as quoted in Gammie \& Matson, 2007; Beard, Schweiger \& Surendran, 2008; Ballintine \& McCourt Larres, 2009; IFAC, 2010; Paulson, 2011; Avramenko, 2012; Low et al., 2013. 
(IB) 3. Maintains and demonstrates competence and recognises limits

Adler \& Milne, 1995; Davey et al., 1999; Paulson, 2011; Slavin, 1996 as quoted in Everaert \& Opdecam, 2012; Hu et al., 2013.

(IB) 4. Strives to add value in an innovative manner

Adler \& Milne, 1995; Adler \& Milne, 1997; Cheetham \& Chivers, 2001; Davis et al., 2001; Dyball et al., 2010; Maesin et al., 2010; Paulson, 2011.

(IB) 5. Manages change

Adler \& Milne, 1995; Adler \& Milne, 1997.

(IB) 6. Treats others in a professional manner

Adler \& Milne, 1995; AECC, 1998; Davis et al., 2001; Miglietti, 2002; Foster \& Lepard, 2003; IFAC, 2006; Gammie \& Matson, 2007; Mitchell, 2008; Ballintine \& McCourt Larres, 2009; Stainbank, 2009; Dyball et al., 2010; Maesin et al., 2010; HKICPA, 2011; Paulson, 2011; Brown, Parente \& Stephan, 2012; Everaert \& Opdecam, 2012.

(IB) 7. Understands the national and international environment

Berry, 1993; Adler \& Milne, 1995; Adler \& Milne, 1997; Davey et al., 1999; Davis et al., 2001; Stainbank, 2009; Dyball et al., 2010; Stainbank, 2010; Paulson, 2011; Avramenko, 2012; Brown et al., 2012; Marsden \& Stanley, 2013; Van der Merwe, 2013.

(IB) 8. Is a life-long learner

Adler \& Milne, 1995; AECC, 1998; Anderson \& Cunningham, 2005; Institute of Chartered Accountants of Ireland (ICAI), 2009; ICAI, 2010; SAICA, 2011; Jones, 2013.

(IB) 9. Works effectively as a team member

Riccio \& Sakata, n.d.; Berry, 1993; Albrecht et al., 1994; Adler \& Milne, 1995; AAA, 1995; AECC, 1995; Sullivan, 1996; Adler \& Milne, 1997; AECC, 1998; Davey et al., 1999; Rooff-Steffen, 1991, as quoted in Thomas 2000; Davis et al., 2001; Cargill et al., 2002; Miglietti, 2002; Foster \& Lepard, 2003; Jayaprakash, 2005; IFAC, 2006; Race, 2001, as quoted in Gammie \& Matson, 2007; Beard et al., 2008; Mitchell, 2008; Ballintine \& McCourt Larres, 2009; Ramsay, Hanlon \& Smith, 2000 as quoted in Stainbank, 2009; Dyball et al., 2010; IFAC, 2010; Maesin et al., 2010; SAICA, 2011; HKICPA, 2011; Paulson, 2011; Brown et al., 2012; Everaert \& Opdecam, 2012; Van der Merwe, 2013.

(IB) 10. Manages time effectively

Berry, 1993; AECC, 1995; Adler \& Milne, 1997; Gammie \& Matson, 2007; Everaert \& Opdecam, 2012; Van der Merwe, 2013.

(IC) PROFESSIONAL SKILLS

(IC) 1. Obtains information

Berry, 1993; Adler \& Milne, 1995; Adler \& Milne, 1997; Davey et al., 1999; Davis et al., 2001; Foster \& Lepard, 2003; Anderson \& Cunningham, 2005; Stainbank, 2010; Paulson, 2011; Rainsbury \& Malcolm, 2003 as quoted Hu et al., 2013; Van der Merwe, 2013.

(IC) 2. Examines and interprets information and ideas critically

Berry, 1993; Adler \& Milne, 1995; AAA, 1995; AECC, 1995; Gainen, 1983, as quoted in Kimmel, 1995; Sullivan, 1996; Adler \& Milne, 1997; Davis et al., 2001; Foster \& Lepard, 2003; Anderson \& Cunningham, 2005; Jayaprakash, 2005; Ballintine \& McCourt Larres, 2009; Maesin et al., 2010; Stainbank, 2010; HKICPA, 2011; Paulson, 2011; Avramenko, 2012; Everaert \& Opdecam, 2012; Hu et al., 2013. 


\section{(IC) 3. Solves problems and makes decisions}

Riccio \& Sakata, n.d.; Berry 1993; Albrecht et al., 1994; Adler \& Milne, 1995; AAA, 1995; AECC, 1995; Adler \& Milne, 1997; AECC, 1998; Rooff-Steffen, 1991, as quoted in Thomas 2000; Davis et al., 2001; Miglietti, 2002; Foster \& Lepard, 2003; Anderson \& Cunningham, 2005; IFAC, 2006; Race, 2001, as quoted in Gammie \& Matson, 2007; Ballintine \& McCourt Larres, 2009; IFAC, 2010; Brown, 2008, as quoted in Maesin et al., 2010; Stainbank, 2010; HKICPA, 2011; Paulson, 2011; Brown et al., 2012; Everaert \& Opdecam, 2012; Marsden \& Stanley, 2013.

(IC) 4. Communicates effectively and efficiently

Riccio \& Sakata, n.d.; Cottell \& Millis, 1992; Berry, 1993; Albrecht et al., 1994; Adler \& Milne, 1995; Adler \& Milne, 1997; AECC, 1998; Rooff-Steffen, 1991, as quoted in Thomas 2000; Cheetham \& Chivers, 2001; Davis et al., 2001; Cargill et al., 2002; Miglietti, 2002; Foster \& Lepard, 2003; Jayaprakash, 2005; IFAC, 2006; Race, 2001, as quoted in Gammie \& Matson, 2007; Ballintine \& McCourt Larres, 2009; Stainbank, 2009; IFAC, 2010; Brown, 2008, as quoted in Maesin et al., 2010; Stainbank, 2010; HKICPA, 2011; Paulson, 2011; SAICA, 2011; Avramenko, 2012; Brown et al., 2012; Hu et al., 2013; Van der Merwe, 2013.

\section{(IC) 5. Manages and supervises}

Riccio \& Sakata, n.d.; Albrecht et al., 1994; Adler \& Milne, 1997; Thomas 2000; IFAC, 2006; Gammie \& Matson, 2007; Stainbank, 2009; IFAC, 2010; Paulson, 2011; Avramenko, 2012.

(IC) 6. Understands how IT impacts a CA's daily functions and routines

Berry, 1993; Davis et al., 2001; Chapman \& DeBerg, 2012; Van der Merwe, 2013.

(IC) 7. Considers basic legal concepts

Marsden \& Stanley, 2013.

Source: Author's analysis

The above table provides evidence that all 25 (eight IA, ten IB and seven IC) of SAICA's pervasive skills can be developed using collaborative learning exercises as each competency is linked to one or more source. Given this knowledge, if academics were to employ this method in their academic programmes, they could similarly address all 25 pervasive skills.

In addition, TABLE 1 illustrates that academics have been employing collaborative learning exercises since 1992 (Cottell \& Millis, 1992), and that this method is currently used (Hu et al., 2013; Low et al., 2013; Van der Merwe, 2013). There are number of sources cited for the skills: 'works effectively as a team member'; 'communicates effectively and efficiently'; and 'solves problems and makes decisions'. This indicated by these skills having in excess of 24 sources. Furthermore, apparent from TABLE 1 , is that the IB and IC competencies have more sources sited to these categories. This provides evidence that these skills can be more easily developed in comparison to the IA category.

\section{RESEARCH METHOD}

To achieve the objective of this study, a structured web-based questionnaire was used as a research instrument. The questionnaire set out to ascertain whether academics use collaborative learning exercises and to obtain their views on how effective this method is in transferring pervasive skills to students. The questionnaire was distributed to all the accounting academics who instruct aspirant CAs at SAICA's academic programmes (SAICA, 2012). 
The questionnaire consisted of three sections of mostly closed-ended questions of a quantitative nature. Comments boxes that comprised the qualitative aspect of the questionnaire were included at the end of each section, allowing descriptive responses to enrich and expand the research results.

The questionnaires were pilot tested by a selected group of academics. A data controller was used to set up an online website where the questionnaire could be answered and the data recorded. The questionnaire, containing a dedicated uniform reference (URL), was sent via email to academics at the SAICA-accredited academic programmes. The participants were directed to a website and asked to complete the questionnaire by clicking on the URL. The completed questionnaires were electronically collated by the data controller. Means, medians, standard deviations, minimums and maximums were calculated.

The population for the empirical work included all the accounting academics who provide instruction to aspirant CAs at all of SAICA's accredited academic programmes (SAICA, 2012). In total, 443 emails were sent to the academics with an URL to the questionnaire and 147 academics responded. Note that none of the questions in the questionnaire was compulsory and the participants could refrain from answering a particular section or questions in a section. This explains why the participants did not necessarily answer all the questions. For section one, the effective response rate was $33 \%(147 / 443)$, for section two, $32 \%(142 / 443)$ and for section three, $32 \%(143 / 443)$. These response rates are higher than those of other web-based questionnaires performed in SA (Eiselen \& Nkoutchou, 2012).

\section{EMPIRICAL FINDINGS}

\subsection{Academics' views on the use collaborative learning exercises during their academic programmes}

In the first section, academics were asked to indicate whether they use collaborative learning exercises in their academic programmes for development. The data analysis of this question is set out in TABLE 2 and is based on the use of collaborative learning exercises subsequent to SAICA releasing its CF. This is indicated by the number of participants who noted that they use collaborative learning exercises and is presented in the "applied" column. A percentage has been calculated, using the applied column, which represents the percentage of participants who indicated that they use this method.

TABLE 2: Academics' views on their use of collaborative learning exercises after SAICA introduced the CF

\begin{tabular}{lccc}
\hline & Applied & $\%$ & $n$ \\
\hline The use of collaborative learning exercises for purposes of development & 55 & 37.4 & 147 \\
\hline
\end{tabular}

Source: Author's analysis

Applied = number of academics who use collaborative learning exercises, $\%=$ percentage of academics who use collaborative learning exercises, $n=$ number of participants who answered the question

The results above are surprising given the findings in the literature review (see TABLE 1). Collaborative learning exercises have effectively been utilised since 1992 (Cottell \& Millis, 1992). 
Therefore, it would be expected that more than $37.4 \%$ of academics would employ this method. Even as far back as 1986, the AAA posited that students should be active in the classroom space, by doing group research projects (AAA, 1986).

One possible explanation for the above results is that academics use methods other than collaborative learning exercises that are also effective in addressing pervasive skills. This is evident in a comment made by one of the participants that "there is a need for a platform for lecturers to share methods or techniques that they have found to be successful in terms of delivering pervasive skills to students, especially in larger classes". Therefore, it needs to be ascertained why academics are not using collaborative learning exercises and which methods they are using to develop the pervasive skills. Furthermore, given the number of sources used to address the skills: 'works effectively as a team member', 'communicates effectively and efficiently' and 'solves problems and makes decisions' (see TABLE 1 ). It would be interesting to determine what methods academics are employing to address these skills.

\subsection{Academics' views on the use of collaborative learning exercises to develop categories IA, IB and IC of the pervasive skills}

In the second section, the views of academics were sought on whether collaborative learning exercises can be applied in the development of category IA, IB and IC. The data analysis of this question is set out in TABLE 3 and is based on whether academics hold that collaborative learning exercises can be applied in the development of the three categories of pervasive skills. A percentage has been calculated based on the applied column, representing the percentage of participants who indicated that this method could be applied in the development of each category.

TABLE 3: Academics' views on whether collaborative learning exercises can be applied in the development of category IA, IB and IC

\begin{tabular}{lcccccccc}
\hline & \multicolumn{1}{c}{ IA } & & \multicolumn{3}{c}{ IB } & & \\
\hline & Applied & $\%$ & Applied & $\%$ & Applied & $\%$ & $n$ \\
$\begin{array}{l}\text { The use of collaborative learning } \\
\text { exercises for purposes of development }\end{array}$ & 51 & 35.9 & 74 & 52.1 & 68 & 47.9 & 142 \\
\hline
\end{tabular}

Source: Author's analysis

Applied = number of academics who indicated that collaborative learning exercises can be applied; \% = percentage of academics who indicated that collaborative learning exercises can be applied; $n=$ number of participants who answered the question

From the results above, more academics indicated that collaborative learning exercises could be used in the transfer of category IB and IC of the pervasive skills (TABLE 3 ) than academics who actually employ this method (TABLE 2). Therefore, these results suggest the possible further use of collaborative learning exercises in the academic programmes.

In addition, academics' indicated that collaborative learning exercises can be applied more effectively when addressing category IB compared to the other two categories. Considerably more academics indicated that category IC can be addressed using collaborative learning exercises than category IA. This is in agreement with the literature review (see TABLE 1). 
Also thought-provoking, was that one academic was of the opinion that pervasive skills could only be developed after the academic programme by remarking, "I believe most of the pervasive skills are only acquired or developed during practical experience". This view was shared by another academic who said, "Whilst doing articles you learn the most and the best is that it is real life scenario's happening every day". Therefore, academics should create collaborative learning "practical experience" scenarios where students can replicate "real life scenarios".

\subsection{Academics' views on other factors impacting the development of pervasive skills}

In the third section, academics were asked to indicate whether active participation by students is required in the development of pervasive skills. The data analysis of this question is set out in TABLE 4. A five-point Likert scale was used by participants to rate the statements presented below: 1 = don't agree at all; 2 = agree to a lesser extent; 3 = agree to a moderate extent; 4 = agree to a large extent; and $5=$ agree completely.

TABLE 4: Academics' views on active participation by students in developing pervasive skills:

\begin{tabular}{llllllllllll}
\hline & 1 & 2 & 3 & 4 & 5 & $n$ & $M$ & Md & SD \\
\hline $\begin{array}{l}\text { Active participation by students during } \\
\text { class is essential in ensuring students }\end{array}$ & 3 & 10 & 21 & 54 & 55 & 143 & 4.03 & 4.00 & 1.003 \\
develop pervasive skills & & & & & & & & & & & \\
$\begin{array}{l}\text { Active participation by students during } \\
\begin{array}{l}\text { collaborative learning exercises is essential } \\
\text { in ensuring students develop pervasive } \\
\text { skills }\end{array}\end{array}$
\end{tabular}

Source: Author's analysis

$M=$ Mean; $M d=$ Median; and SD = Standard deviation

The majority of academics (76\%) either "agreed completely" or "agreed to a large extent" that active participation by students during class is essential in ensuring that students develop competencies. Similarly, the majority of academics (85\%) also either "agreed completely" or "agreed to a large extent" that active participation during collaborative learning exercises ensures that students are equipped with competencies. These findings are consistent with the views reflected in the literature review that active participation by students results in the transfer of pervasive skills (AECC, 1998; Davis, Dudley \& McGrady, 2001; Frank et al., 2010). Therefore, it is imperative that academics act as facilitators during collaborative learning exercises, and allow students to be active participants during the learning process.

\section{CONCLUSIONS, RECOMMENDATIONS AND FURTHER RESEARCH}

There is a need for academics to go beyond the teaching of merely technical skills in order to produce aspirant CAs who are capable of entering the work environment. The paper set out to examine the extent to which SA accounting academics use collaborative learning exercises in their teaching, and how effective they view this method to be in transferring pervasive skills to students. Firstly, the results indicated that fewer than expected academics use collaborative 
learning in the development of pervasive skills. Given that as far back as 1986, the AAA advocated this method to be effective in the transfer of skills, and that this method has been used by academics since 1992 in the development of skills. Therefore, a greater awareness needs to be created among academics on the effectiveness of collaborative learning exercises in developing pervasive skills. Secondly, an academic remarked that there is a need for lecturers to work together to find methods that are successful in developing pervasive skills. Consequently, there is potential for academics to collaborate with each other on methods that result in the transfer of pervasive skills to students. Thirdly, academics should create practical collaborative learning experiences that replicate real working environments, where students can be active participants in the learning process. An academic's role as facilitator is also pivotal to the collaborative learning exercise. Lastly, it was evident that academics' view that collaborative learning exercises can more effectively address category IB and IC of the pervasive skills, which is in agreement with the literature.

This study is particularly valuable to the SA situation given the adoption of the CF. It can also inform academics, both locally and internationally, on the effectiveness of collaborative learning exercises in transferring competencies, given that SAICA's pervasive skills are aligned to the competencies of other professional accounting bodies.

Further research is needed to establish why academics are not using collaborative learning exercises in their academic programmes. This study could also be extended to include the effectiveness of other methods in transferring pervasive skills to students.

\section{LIST OF REFERENCES}

Accounting Education Change Commission (AECC) (1990). Position Statement Number One: Objectives of education for accountants. Available: https://aaahq.org/AECC/pdf/position/posl.pdf. (Accessed 19 0ctober 2011).

Accounting Education Change Commission (AECC) (1995). Issues Statement Number Six: Transfer of academic credit for the first course in accounting between two-year and four-year colleges. Available: http://aaahq.org/aecc/pdf/position/issues6.pdf. (Accessed 19 0ctober 2011).

Accounting Education Change Commission (AECC) (1998). The accounting education change commission grant experience: A summary. Available: https://aaahq.org/AECC/changegrant/cover.htm. (Accessed 19 0ctober 2011).

Adler, R.W. \& Milne, M.J. (1995). Increasing learner-control and reflection: towards learning-to-learn in an undergraduate management accounting course. Accounting Education, 4(2), pp. 105-119.

Adler, R.W., \& Milne, M.J. (1997). Improving the quality of accounting students' learning through action-orientated learning tasks. Accounting Education, 6(3), pp. 191-215.

Albrecht, W.S., Clark, D.C., Smith, J.M., Stocks, K.D. \& Woodfield, L.W. (1994). An accounting curriculum for the next century. Issues in Accounting Education, 9(2), pp. 401-425.

Albrecht, W. \& Sack, R. (2000). Accounting education: Charting the course through a perilous future. Accounting Education Series. American Accounting Association, Sarasota: FL.

American Accounting Association (AAA) (1986). The Bedford Report, Future accounting education: Preparing for the expanding profession. Available: https://aaahq.org/AECC/future/index.htm.

(Accessed 31 May 2013). 
American Accounting Association (AAA) (1989). Perspectives on Education: Capabilities for success in the accounting profession. Available: https://aaahq.org/AECC/big8/cover.htm. (Accessed 31 May 2013).

American Accounting Association (AAA) (1995). Intentional learning: A process for learning to learn in the accounting curriculum. Available: https://aaahq.org/AECC/intent/cover.htm. (Accessed 19 0ctober 2011).

American Accounting Association (AAA) (1999). The Accounting Education Change Commission: Its history and impact. United States of America: The Accounting Education Change Commission and American Accounting Association.

Anderson, S.C. \& Cunningham, N.A. (2005). A bridge to FARS and information literacy for accounting undergraduates. Journal of Business and Finance Librarianship, 10(3), pp. 3-16.

Avramenko, A. (2012). Enhancing students' employability through business simulation. Education and Training, 54(5), pp. 355-367.

Barac, K. (2009). South African training officers' perceptions of the knowledge and skills requirements of entry-level trainee accountants. Meditari Accountancy Research, 17(2), pp. 19-46.

Ballantine, J. \& McCourt Larres, P. (2009). Accounting undergraduates' perceptions of cooperative learning as a model for enhancing their interpersonal and communication skills to interface successfully with professional accountancy education and training. Accounting Education: An International Journal, 18(4-5), pp. 387-402.

Beard, D., Schweiger, D. \& Surendran, K. (2008). Integrating soft skills assessment through University, College, and Programmatic Efforts at an AACSB Accredited Institution. Journal of Information Systems Education, 19(2), pp. 229-240.

Beattie, V., Collins, B. \& Mclnnes, B. (1997). Deep and surface learning: a simple or simplistic dichotomy? Accounting Education: An International Journal, 6(1), pp. 1-12.

Berry, A. (1993). Encouraging group skills in accountancy students: an innovative approach. Accounting Education, 2(3), pp. 169-179.

Boyce, G., Kelly, A., Williams, S. \& Yee, H. (2001). Fostering deep and elaborative learning and generic (soft) skill development: the strategic use of case studies in accounting education. Accounting Education, 10(1), pp. 37-60.

Brown, R.C., Parente, D.H. \& Stephan, J.D. (2012). Facilitating the acquisition of strategic skills - The role of traditional and soft managerial skills. Management Research Review, 35(11), pp. 1004-1028.

Brungardt, C.J. (2009). College graduates' perceptions of their use of teamwork skills: soft skill development in Fort Hays State University Leadership Education. Doctoral Thesis. Northwestern Oklahoma State University.

Cargill, E., Gammie, B. \& Gammie, ع. (2002). Personal skills development in the accounting curriculum. Accounting Education, 11(1), pp. 63-78.

Cargill, E., Gammie, E. \& Hamilton, S. (2010). Searching for good practice in the development and assessment of non-technical skills in accountancy trainees - a global study. Aberdeen, Scotland: The Robert Gordon University.

Chapman, K.J. \& DeBerg, C.L. (2012). Assessing student performance and attitudes based on common learning goals and alternative pedagogies: The case of principles of financial accounting. Academy of Educational Leadership Journal, 16, pp. 63-79. 
Cheetham, G. \& Chivers, G. (2001). How professionals learn in practice: an investigation of informal learning amongst people working in professions. Journal of European Industrial Training, 25(5), pp. 247-292.

Clinton, B.D. \& Kohlmeyer, J.M. (2005). The effects of group quizzes on performance and motivation to learn: Two experiments in cooperative learning. Journal of Accounting Education, 23(2), pp. 96-119.

Coetzee, S., Joubert, B. \& Oberholzer, R. (2009). Tax topics a trainee chartered accountant should be taught: a survey of perceptions in and outside public practice. Meditari Accountancy Research, 17(1), pp. 15-31.

Cottell, P.G. \& Millis, B.J. (1992). Cooperative learning in Accounting. Journal of Accounting Education, 10, pp. 95-111.

Cotton, W.D.J., Rainsburg, E. \& Scott, G. (2002). Competency based professional accounting certification in New Zealand. Article presented at the American Accounting Association Conference: Ohio.Email to: mstrauss@uj.ac.za, from: Bill.Cotton@nzica.co.za. (Dated 29 November 2011).

Creswell, J.W. (2011). Educational research: planning, conducting, and evaluating quantitative and qualitative research. Boston: Pearson Education Inc.

Davey, H., Haigh, N. \& Kelly, M. (1999). Contemporary accounting education and society. Accounting Education, 8(4), pp. 321-340.

Davis, H.H., Dudley, L.W. \& McGrady, D.G. (2001). Using an investment project to develop professional competencies in Introduction to Financial Management. Journal of Education for Business, January/February 2001, pp. 125-131.

De Villiers, R. (2010). The incorporation of soft skills into accounting curricula: preparing accounting graduates for unpredictable futures. Meditari Accountancy Research, 18(2), pp. 1-22.

Drennan, L. \& Kavanagh, M.H. (2008). What skills and attributes does an accounting graduate need? Evidence from student perceptions and employer expectations. Accounting and Finance, 48, pp. 279300.

Dyball, M.D., Reid, A., Ross. P. \& Schoch, H. (2010). Compulsory group work - accounting students' conceptions and suggestions. Asian Review of Accounting, 18(2), pp. 92-105.

Eiselen, R., \& Nkoutchou, H. (2012). Retirement saving behaviour of young adults in the financial services sector. Journal of Economic and Financia/ Sciences, 5(1), pp. 31-48.

Everaert, P., \& Opdecam, દ. (2012). Improving student satisfaction in a first-year undergraduate accounting course by team learning. Issues in Accounting Education, 27(1), pp. 53-82.

Foster, A.G., \& Lepard, D.H. (2003). Powerful leadership development. California: Corwin Press, Inc. Francis, G., \& Samkin, G. (2008). Introducing a learning portfolio in an undergraduate financial accounting course. Accounting Education: An International Journal, 17(3), pp. 233-271.

Frank, G., Gradisher, S., \& Ofobike, દ. (2010). Teaching business ethics: A quandary for accounting educators. Journal of Education for Business, 85, pp. 132-138.

Gammie, $\varepsilon$., \& Joyce, Y. (2009). Competence-based approaches to the assessment of professional accountancy training work experience requirements: The ICAS experience. Accounting Education: An International Journal, 18(4-5), pp. 443-466.

Gammie, E., \& Matson, M. (2007). Group assessment of final degree level: An evaluation. Accounting Education: An International Journal, 16(2), pp. 185-206. 
Hong Kong Institute of Certified Public Accountants (HKICPA) (2011). Information paper on enhancements. Available:

http://appl.hkicpa.org.hk/oldsite/students(NEW)/download/qp/info_paper.pdf. (Accessed 19 October 2011).

Houghton, T., \& Proscio, T. (2001). Hard work on soft skills: Creating a "culture of work" in workforce development. A publication of Public/Private Venues: New York.

Hu, B., Kern, T., McGuigan, N., \& Weil, S. (2013). Using asynchronous discussion forums to create social communities of practice in financial accounting. Pacific Accounting Review, 25(1), pp. 30-57.

Institute of Chartered Accountants of Ireland (ICAI) (2009). Chartered Accountants Ireland Competency Statement CA Proficiency 1. Available:

http://www.charteredaccountants.ie/Global/syllabus/CAPl $\% 20$ Competency $\% 20$ statement $\% 20 \% 202$ 009\%202010.pdf. (Accessed 28 July 2010).

Institute of Chartered Accountants of Ireland (ICAI) (2010). New Syllabus. Available: http://www.charteredaccountants.ie/Students/Student-Services/Courses/New-Syllabus/. (Accessed 28 July 2010).

International Federation of Accountants (IFAC) (2006). Approaches to the development and maintenance of professional values, ethics and attitudes in accounting education programmes. Available: http://www.accountingweb-cgi.com/whitepapers/approaches_to.pdf. (Accessed 29 September 2011).

International Federation of Accountants (IFAC) (2010). Handbook of International Education Pronouncements. Available: http://web.ifac.org/publications/international-accounting-educationstandards-board/handbook. (Accessed 23 September 2010).

International Federation of Accountants (IFAC) (2014). Member bodies. Available:

http://www.ifac.org/about-ifac/membership/members. (Accessed 3 September 2014).

Jayaprakash, J.C.M. (2005). Strategies in teaching accounting in higher education. Available: http://otl.curtin.edu.au/tlf/tlf2005/refereed/jayaprakashj.html. (Accessed 18 August 2011).

Jones, J.P. (2013). The impact of the supplemental instruction leader on student performance in introductory accounting. American Journal of Business Education, 6(2), pp. 247-254.

Kermis, G., \& Kermis, M. (2010). Professional presence and soft skills: a role for accounting education. Journal of Instructional Pedagogies, 2, pp. 1-10.

Kimmel, P. (1995). A framework for incorporating critical thinking into accounting education. Journal of Accounting Education, 13(3), pp. 299-318.

Lehmann, C.M., Rose, A.M., \& Strand Norman, C. (2004). Cooperative learning: resources from the business disciplines. Journal of Accounting Education, 22, pp. 1-28.

Low, M., Samkin, G., \& Liu, C. (2013). Accounting education and the provision of soft skills: Implications of the recent NZICA CA academic requirement changes. E-journal of Business Education and Scholarship of Teaching, 7(1), pp. 1-33.

Maesin, A., Mansor, M., Nayan, S., Osman, N., \& Shafie, L.A. (2010). The practice of collaborative learning among lecturers in Malaysia. Management Science and Engineering, 4(2), pp. 115-123.

Marsden, S., \& Stanley, T. (2013). Accountancy capstone: Enhancing integration and professional identity. Journal of Accounting Education, 31, pp. 363-382. 
McVay, G.J., Murphy, P.R., \& Wook Yoon, S. (2008). Good practices in accounting education: Classroom configuration and technological tools for enhancing the learning environment. Accounting Education: An International Journal, 17(1), pp. 41-63.

Miglietti, C. (2002). Using cooperative small groups in introductory accounting classes: A practical approach. Journal of Education for Business, November/December 2002, pp. 111-115.

Mitchell, G.W. (2008). Essential soft skills for success in the twenty-first century workforce as perceived by the Alabama Business/Marketing educators. Doctoral Thesis. Auburn University.

Oxford Dictionary (2014a). Definition of soft skills. Available:

http://www.oxforddictionaries.com/definition/english/soft-skills?q=soft+skills. (Accessed 6 0ctober 2014.

Oxford Dictionary (2014b). Definition of collaborative. Available:

http://www.oxforddictionaries.com/definition/english/collaborate? $q=$ collaborating+with. (Accessed 6 0ctober 2014).

Paulson, $\varepsilon$. (2011). Group communication and critical thinking competence development using a reality-based project. Business Communications Quarterly, 74(4), pp. 399-411.

Riccio, E.L., \& Sakata, M.C.G. (n.d.). Teaching - learning methods in accounting education: An empirical research in the Brazilian scenario. Available:

http://www.tecsi.fea.usp.br/riccio/tac/pdf/IAAER45.pdf/. (Accessed 18 August 2011).

South African Institute of Chartered Accountants (SAICA) (2009). Competency Framework. Competencies of a Chartered Accountant (SA) at entry point to the profession. Available: http://saica.co.za/Portals/0/Documents/CompetencyframeworkCAs.pdf. (Accessed 8 March 2010).

South African Institute of Chartered Accountants (SAICA) (2011). Accreditation Criteria. Applications for new and continued accreditation.Email to: mstrauss@uj.ac.za, from: mandio@saica.co.za. (Dated 29 September 2011).

South African Institute of Chartered Accountants (SAICA) (2012). List of SAICA accredited programmes 2012. Available:

https://www.saica.co.za/Portals/0/LearnersStudents/documents/List $\% 20$ of\%20 accredited\%20programmes\%202012.pdf. (Accessed 30 March 2012).

Stainbank, L.J. (2009). Working in teams: improving the team experience. Meditari Accountancy Research, 17(1), pp. 69-80.

Stainbank, L.J. (2010). Students' perceptions of the usefulness of an accounting project in acquiring accounting knowledge and professional skills. SA Journal of Accounting Research, 24(1), pp. 79-100.

Sullivan, E.J. (1996). Teaching financial statement analysis: a cooperative learning approach. Journal of Accounting Education, 14(1), pp. 107-111.

Sundem, G.L (1999). The Accounting Education Change Commission: Its history and impact. The Accounting Education Change Commission and American Accounting Association, Sarasota: United States of America.

Stovall, D.C., \& Stovall, P.S. (2009). Professional Accountants: Void of "soft skills"? The Business Review Cambridge, 14(1), pp. 99-104.

Thomas, T.A. (2000). A teaching environment for learning soft skills applicable to Information Systems Development. Doctoral Thesis. University of Pretoria. 
Van der Merwe, N. (2013). An evaluation of an integrated case study and business simulation to develop professional skills in South African Accountancy Students, International Business and Economics Research Journal, 12(10), pp. 1137-1156.

Van der Schyf, D.B. (2008). Five recent developments' impact on the traditional academic culture of departments of accounting at South African universities. Meditari Accountancy Research, 16(2), pp. $1-12$. 


\title{
APPENDIX
}

\section{LIST OF ABBREVIATIONS AND ACRONYMS}

\author{
AAA American Accounting Association \\ AECC Accounting Education Change Commission \\ CA Chartered Accountant \\ CF Competency Framework \\ HKICPA Hong Kong Institute of Certified Public Accountants \\ IA Category of pervasive skills: Ethical behaviour and professionalism \\ IB Category of pervasive skills: Personal attributes \\ IC Category of pervasive skills: Professional skills \\ ICAI Institute of Chartered Accountants in Ireland \\ IFAC International Federation of Accountants \\ SA South Africa \\ SAICA South African Institute of Chartered Accountants \\ URL Uniform Reference
}

